\title{
Sob a frágil luz do anjo - entre a tradição e a
}

\section{modernidade}

\section{Maria João Cantinho *}

\section{Resumo}

É bastante conhecida a importância da escrita de Franz Kafka nos pensamentos de Walter Benjamin e Gershom Scholem, que por muitas razões em sua juventude eram fascinados pelo enigmático trabalho de Kafka. Mais tarde, esse fascínio mudou e o interesse de ambos tornou-se o centro de seu próprio trabalho e filosofia. Em sua obra, Kafka expressa toda a ambivalência e o estranhamento da relação entre a modernidade da experiência e a tradição judaica, que é a lareira de toda a filosofia judaica, ainda que os temas abordados neste campo sejam diversificados: história, línguas, política e alegoria. Neste caso em particular, a parte mais importante é a relação entre o pensamento de Walter Benjamin e a escrita (e pensamento) de Franz Kafka. Dois anjos e duas diferentes visões de catástrofe. O primeiro questionamento é: Qual o significado de tradição para Benjamin e Kafka? O segundo questionamento é um paradoxo: Seria possível procurar da mesma forma pelo passado e pela tradição sob a "frágil luz do anjo"?

Palavras-chave: Benjamin, Kafka, Tradição judaica, Modernidade, Alegoria.

\section{Abstract}

Under the weak light of the angel - between tradition an modernity

To Walter Benjamin's and Gershom Scholem's thought, the importance of Franz Kafka's writing is much known. By the time of their youth, they were for many reasons very fascinated by Kafka's enigmatic work. Later, that fascination changed, and the interest from both of them became the main part of their own work and philosophy. In his work, Kafka expresses all the ambivalence and strangeness of the modernity of the experience and the Jewish tradition relation. Furthermore, he states that this is the hearth of all the Jewish philosophy, even if the themes covering this field are diversified: History, Language, Politics and Allegory. Particularly in our case, the most important part is the relation between Walter Benjamin's thought and Kafka's writing (and thinking). Kafka and Benjamin: Two angels and two different visions of catastrophe. The first question is: What is the meaning of tradition for 
Benjamin and Kafka? The second question is a paradox: Is it possible, in the same way, to look for the past and for the tradition, under the "weak light of the angel"?

Key-words: Benjamin, Kafka, Jewish tradition, Modernity, Allegory. 


\section{Sob a frágil luz do anjo - entre a tradição e a modernidade}

"Nur um der Hoffnungslosen willen ist uns die Hoffnung gegeben”

WALTER BENJAMIN, Goethes Wahlverwandschaften”, G.S. 1,1, p. 201

Um mesmo canto atravessa os textos de Scholem, Benjamin e Kafka. Também em Kafka, "refém" da visão catastrófica e alegórica do mundo e da história, aparece a visão de um anjo - uma imagem profundamente onírica que o autor descreve no seu diário, com a data de 25 de Junho de 1914. Apresentada sob a forma de uma história contada na primeira pessoa, talvez seja o esboço de uma história que ele nunca chegou a publicar.

Kafka descreve um quarto onde o seu locatário tinha andado às voltas, durante todo o dia, sob o signo da inquietação e do tédio. Por entre as cores, que se metamorfoseavam e onde as formas inquietamente se moviam, prepara-se a epifania:

A aparição preparava-se, a qual me iria libertar (...) Descendo de muito alto (...) um anjo envolto em roupas de um violeta azulado ornamentadas por cordões dourados desce lentamente na penumbra com as suas grandes asas brancas, brilhantes como seda, enquanto o seu braço elevado estendia horizontalmente a espada. «Eis um anjo, pensava eu, ele voava ao meu encontro durante todo o dia e eu, incrédulo, não o sabia. Agora ele vai falar-me». E eu baixava os olhos, mas quando os levantava, o anjo ainda ali estava (...) mas já não era um anjo vivo, era simplesmente uma figura de proa em madeira pintada, como aquelas que vemos suspensas ao fundo das tabernas. Nada mais. O pomo da espada estava disposto de maneira a poder servir de candelabro (...) eu tinha tirado a lâmpada eléctrica, mas não queria continuar no escuro, tinha ainda uma candeia, subi a uma cadeira, fixei a candeia no pomo da espada, alumiei-a e permaneci sentado até a uma hora muito avançada na noite sob a frágil luz do anjo. ${ }^{1}$.

\footnotetext{
* Maria João Cantinho é pesquisadora do Centre de Recherche Esthétique Musicale et de Philosophie Contemporaine da Universidade Sorbonne IV. Redige a tese de doutoramento subordinada ao tema Messianismo, Marxismo e Melancolia na obra de Walter Benjamin.

${ }^{1}$ Cf. KAFKA, Journal, traduction et présentation par Marthe Robert, ed. Grasset, Paris, 1954, pp. 371, 372.
} 
Este texto, descrevendo uma visão enigmática de Kafka, desconcerta-nos e lança-nos na perplexidade. Num mundo como o de Kafka, onde a profecia perdeu definitivamente o lugar, somos confrontados, de alguma forma, com a esperança, ainda que ela apareça "sob a frágil luz". Este texto é acompanhado, ao mesmo tempo, pela narração tradicional: "as vibrações sísmicas", a iridiscência das cores, o frenesi do observador, a espada de prata que surge e a cintilância e a pureza/brancura das asas. $\mathrm{O}$ anjo, do qual ele espera uma mensagem de libertação, apresenta-se armado (relembrando-nos a estátua da liberdade) e remete-nos para a ideia de uma ameaça potencial que se esconde na promessa da redenção. A dinâmica desta epifania, se comparada com a imagem alegórica do anjo benjaminiano e de Scholem, nada tem a ver com o desespero deste. No final, o anjo aparece como uma simples figura, grosseira, um simples artefacto humano, que pode ser usado como um sustentáculo de um candelabro ou de uma candeia.

Este anjo quase nada tem a ver com o anjo benjaminiano, de olhar esbugalhado, assistindo à catástrofe da história, tentando em vão recolher os destroços, de asas presas pela tempestade do futuro:

Há um quadro de Klee chamado Angelus Novus. Vê-se aí um anjo que tem o ar de se afastar de qualquer coisas a que o seu olhar parece fixar-se. Os seus olhos são esbugalhados, a sua boca está aberta e as suas asas são abertas. Tal deverá ser o aspecto que apresenta o anjo da História. O seu rosto está virado para o passado. Aí, onde o nosso olhar nos parece repartir-se numa sucessão de acontecimentos, ele não vê senão um único que se oferece ao seu olhar: uma catástrofe sem modulação nem tréguas, amontoando os escombros e projectando-os eternamente diante dos seus pés. O Anjo desejaria debruçar-se sobre este desastre, curar as feridas e ressuscitar os mortos. Mas uma tempestade elevou-se, vinda do Paraíso; prende as asas abertas do Anjo e ele não consegue libertá-las. Esta tempestade empurra-o para o futuro, para o qual o Anjo mantém as costas voltadas, enquanto os escombros, diante dele, sobem até ao céu. Nós damos o nome de Progresso a esta tempestade. ${ }^{2}$

\footnotetext{
${ }^{2}$ WALTER BENJAMIN, G.S., I, 2, tese IX, pp. 697, 698.
} 
O carácter profético do anjo de Kafka perdeu, logo à partida, o seu poder, revelando-se como uma ilusão, assumindo a forma de um grosseiro objecto. Este anjo, como nota Robert Alter ${ }^{3}$, "pode ser um refugiado do paraíso", tal como o anjo de Benjamin, mas "que não terá a capacidade de olhar para trás". Contrariamente ao anjo de Benjamin que, obsessivamente se volta para o passado, mas que é paradoxalmente empurrado para o futuro e paralisado pela tempestade do progresso, o anjo de Kafka revela-se, ouso dizê-lo, a própria "caricatura da redenção", petrificado na sua forma objectal e definitiva.

A pungência do olhar do Angelus Novus, em toda a sua dilaceração alegórica, não existe no anjo de Kafka (talvez a adivinhemos no olhar daquele que se senta sob a frágil candeia). A promessa que parecia anunciada, com o esplendor da epifania e do acontecimento sagrado, no seu início, facilmente se dissipou e se transformou numa ilusão. Transformado em simples objecto, como as figuras de madeira pintadas que se encontram no fundo das tabernas, ele não deixa de ser um "utensílio" de iluminação, um objecto certamente anacrônico, mas, ainda assim, passível de ser usado.

Este homem (o narrador) que, por algum tempo, parecia ter sucumbido ao fascínio da sua visão, cedo compreende o logro, a ilusão que se oculta sob a "máscara da epifania". No entanto, leva a cabo o gesto de recusa da lâmpada eléctrica - símbolo da modernidade -, decidindo, ao invés, utilizar uma candeia que pendura no pomo da espada do anjo, alumiando o escuro. Sob a frágil luz da candeia, permanece obstinadamente sentado, por não querer mergulhar na escuridão da noite (a "escuridão do passado"?), sob a "frágil luz do anjo". Desfeitas as grandes ilusões, como a promessa da redenção, resta ainda a "frágil luz da tradição"4. Esta admirável parábola põe bem à vista o dilema kafkiano (que é também o de Benjamin e o de Scholem e de uma juventude aculturada) entre a tradição e a modernidade. E é precisamente este o tema que aqui abordamos.

Ainda que Kafka não tenha sido um pensador pertencente à mesma constelação filosófica de Gershom Scholem, de Franz Rosenzweig, de Walter Benjamin e de Ernst Bloch,

\footnotetext{
${ }^{3}$ Les Anges Nécéssaires, Les Belles Lettres, Paris, 2001, p. 199.

${ }^{4}$ Não posso deixar de evocar a relação metafórica que nos surge inopinadamente entre a expressão "a frágil luz da candeia" e a "frágil força messiânica", que nos chega do passado e da qual Benjamin nos fala na tese II. Cf. G.S., I, 2, p. 694: "Dann ist uns wie jedem Geschlecht, das vor uns war, eine schwache messianische Kraft mitgegeben, na welche die Vergangenheit Anspruch hat." Será legítimo estabelecer um paralelo entre estas expressões? É preciso que fique claro que Benjamin e Kafka jamais se cruzaram, mas a preocupação sobre a relação entre a tradição e a modernidade toca-os de muito perto.
} 
não foi, de modo algum, alheio nem indiferente às problemáticas destes pensadores. Em Kafka, não é um pensamento filosófico que perpassa a sua escrita, definida pelo seu carácter enigmático e alegórico, mas ela é, ainda assim, atravessada pelas grandes questões do judaísmo, como a Lei e a Tradição judaica, bem atenta à contemporaneidade do judaísmo, que não deixou incólumes os seus contemporâneos, mas que os tocou profundamente. Uma prova inquestionável é, sem dúvida, a correspondência trocada por Benjamin e Scholem, nos anos 34 e $35^{5}$, bem como a correspondência de Benjamin com Bertold Brecht ${ }^{6}$, os ensaios de Benjamin sobre Kafka, a sua interpretação e, também, a perspectiva brechtiana sobre o autor, num clima marcado pela polêmica e pela controvérsia.

Kafka ocupa um lugar muito especial no panorama cultural alemão. Embora não sendo nem verdadeiramente religioso nem inteiramente assimilado, nem sequer um revolucionário comprometido, encontra-se, no entanto, numa encruzilhada fundamental do pensamento judaico contemporâneo. A única pessoa, entre os autores aqui referidos, com quem mantém relações pessoais é efectivamente Martin Buber. Porém, o pensamento de Kafka influenciou profundamente tanto Benjamin, quanto Scholem, que vê em Kafka um "adepto de uma cabala herética dos tempos modernos" ${ }^{7}$. Scholem explicitará mais tarde esta ideia na sua obra Dez Teses não-históricas sobre a Cabala (Zehn unhistorische Sätze über Kabbala) ${ }^{8}$.

O carácter acentuadamente negativo que assume, na obra de Kafka, tanto o messianismo judaico quanto a utopia libertária, foi importante para os outros autores, como uma marca inalienável do seu pensamento. Ao mesmo tempo, desenha-se uma linha que traça

\footnotetext{
${ }^{5}$ Cf. Briefe II, ao longo de várias cartas. Mas a mais importante das cartas, onde Benjamin expõe a sua argumentação face às objecções de Scholem, é a de 11 de Agosto de 1934, pp. 617-619.

${ }^{6}$ Cf. WALTER BENJAMIN, G.S., VI, "Fragmente Autobiographische Schriften", p. 525.

${ }^{7}$ Scholem era verdadeiramente fascinado pela obra de Kafka e o seu interesse reaparece em várias fases, ao longo de toda a sua obra. Fazendo parte da mesma geração de filhos "perdidos" e rebeldes, face à autoridade paterna, Scholem descobre a sua intensa afinidade com Kafka, sobretudo na questão judaica da Lei. As duas primeiras fases estão muito ligadas à correspondência com Walter Benjamin, devido à intensa discussão que mantêm entre ambos. Havendo um primeiro debate que tem o seu início em 1934 e que atinge o seu auge em 1934, no mesmo preciso momento em que Benjamin redige o ensaio sobre Kafka, a segunda fase é em 1938, novamente numa relação intensa com Walter Benjamin. Após anos de trabalho intenso sobre a mística judaica, não é senão a partir do fim dos anos cinquenta que o nome de Kafka aparece novamente em vários estudos sobre a cabala.

${ }^{8}$ Cf. Scholem, Aux Origines religieuses du Judaïsme Laïque, de la mystique aux Lumières, ed. Calmann-Lévy, Paris, 2000, pp. 255, 256: "Em Praga, um século antes de Kafka, Jonas Wehle escrevia (...) para os últimos adeptos de uma cabala que se tinha virado para a heresia, de um messianismo niilista que se esforçava por falar a língua das Luzes. Ele foi o primeiro a pôr-se essa questão (e a responder-lhe pela afirmativa) de saber se, com a expulsão do homem do Paraíso, não se tinha também perdido o homem." De acordo com Scholem, Kafka seria um seguidor desta "cabala herética", "pois ele tinha dado uma expressão à linha de demarcação que separa a religião do niilismo." O próprio Kafka o diz, no seu diário, em KAFKA, Journal, Grasset, Livre de Poche, Paris, 1954, p. 530: "Toda esta literatura é assalto contra as fronteiras e, se o sionismo não tivesse intervindo, ela teria podido facilmente chegar a uma nova doutrina secreta, a uma cabala."
} 
um dos elos com o pensamento dos outros autores, um elemento de "afinidade electiva", como o ressalta Michael Löwy ${ }^{9}$. A relação de Kafka com o judaísmo, efectivamente tardia, é precedida pela sua imersão na cultura e literatura alemãs, tão características na sua época. A sua ligação com a cultura alemã, porém, não é tão directa como nos restantes autores. Enquanto que os românticos Schlegel, Hölderlin e Novalis exercem o seu fascínio sobre Benjamin, Scholem e Bloch, em Kafka, o autor decisivo será, com efeito, Kleist. Quanto aos outros autores privilegiados por Kafka são Schopenhauer, Nietzsche, Kierkegaard, Flaubert, Tolstoi, Strindberg, etc., numa tradição universal da literatura.

Profundamente marcado pela experiência desencantada do homem moderno - da qual ele nos dá um retrato notável em América, mas também nas suas restantes obras, reflectindo a condição alienada do trabalhador, o universo kafkiano constitui-se como uma crítica lúcida da sociedade industrial moderna, num mundo essencialmente dominado pelo retorno monótono e circular do sempre-igual, pela temporalidade cruel e irreversível do relógio. Uma das fontes principais da obra América foi a do socialista judeu Artur Holitscher (Amerika heute und morgen, publicado em 1912). Dessa repugnância Kafka dá conta a Felice Bauer, em 1913 e dará livre curso à sua hostilidade perante a alienação humana nos anos que se seguirão, criticando o vazio "humano" de que padece o taylorismo, como um monstro sem coração.

9 Utopia e Redenção, Companhia das Letras, S.Paulo, 1989, p. 67. Ver também "Kafka, o insubmisso", editora Azougue, S. Paulo, 2008, pp. 19-57. 


\section{O embaraço de Kafka relativamente ao judaísmo}

(...) teria sido concebível que nós nos tivéssemos reencontrado no judaísmo ou, mesmo, que tivéssemos ficado unidos. Mas o que é que tu me transmitiste do judaísmo?!*

KAFKA, Lettre au père, Gallimard, Folio, 1953, p. 60.

A célebre Carta ao Pai, que Kafka redigiu em 1919, reflecte a sua amargura perante a inconsistência paterna e a sua superficialidade ${ }^{10}$, no modo como este se relaciona com a tradição judaica. A forma como, por exemplo, o pai se relaciona com a questão da Lei, será, para Kafka, um tema central em toda a sua obra. Tal como Benjamin, também Kafka manterá, ao longo da sua vida, uma relação de grande ambiguidade face à cultura e à tradição judaicas. A descrição sarcástica da prática religiosa do pai, à qual ele era forçado a assistir, dá um retrato fiel (e bastante decadente) do descalabro espiritual das comunidades judaicas burguesas, nas grandes cidades da Europa central, tais como Viena, Praga e Berlim, onde a assimilação havia feito esquecer até a língua hebraica, grassando a ignorância dos textos tradicionais e o total desconhecimento das significações metafísicas do judaísmo. Na Carta ao $P a i$, "o narrador identifica-se retrospectivamente ao olhar desmistificador da criança que, para lá da indiferença e do aborrecimento, desmascara o aspecto grotesco de um ritual destituído de sentido."11 Mas, como o nota Mosès, a crítica de Kafka ao pai e o centro da discussão não é que ele tenha imposto ao filho uma lei que ele recusa, mas sim o facto de "ele não ter sabido transmitir a Lei",12, ou a de não a ter sabido transmitir senão de forma residual e superficial. Para o seu pai, o facto de Kafka ser, ao mesmo tempo, um "exemplo" dessa aculturação e da integração no mundo ocidental e revelar o seu fascínio pela tradição à qual tinha escapado,

\footnotetext{
* Elaborei a tradução a partir da edição francesa aí citada.

${ }^{10}$ Gostaria de ressaltar, aqui, que, um dos aspectos que mais tocou Scholem foi, precisamente, a tensão e a rebeldia da relação de Kafka relativamente ao pai. O pai de Scholem, quando este era muito jovem, expulsa o próprio filho de casa, em 1917. Reconciliar-se-ão mais tarde, mas o jovem Scholem será definitivamente marcado por este acontecimento. Como o explica Alter, na sua obra Les Anges Nécéssaires, essa revolta exprime essencialmente a revolta contra as suas origens burguesas, que fazia parte dos traços que caracterizavam a própria intelligentzia europeia moderna (v. pp. 48, 49).

${ }_{11}$ STEPHANE MOSES, L'Ange de L'histoire, p. 212.

12 Ibidem.
} 
parecia-lhe um verdadeiro "escândalo genealógico"13 " "a própria negação do sentido da história" ${ }^{14}$.

A partir de 1910, com a passagem do teatro ídiche pela cidade de Praga, Kafka interessara-se vivamente pelo judaísmo, impelido à descoberta da literatura ídiche e hassídica. Em 1913, essa relação reforça-se com Martin Buber, com quem se correspondeu durante alguns anos. Tal como Benjamin, Kafka chegou ainda a estudar hebraico, alimentando um vago projecto de uma viagem à Palestina. Apesar da sua relação ambígua com a religião judaica, ela é, no entanto, um traço indelével da sua obra ${ }^{15}$. Uma espécie de atmosfera de religiosidade esconde-se nos seus romances, sob a forma da parábola, inquietante e enigmática. A atentar nas palavras do próprio Kafka, ele confessou, no final da sua vida, a sua mais alta aspiração: "a de criar uma nova escrita sagrada - objecto por excelência de exegese." ${ }^{16}$ Ainda que profundamente enigmática, na sua essência, ela foi vivida por Kafka, na própria experiência da escrita, por vezes confessada no seu diário. A esse propósito evocava o carácter de "assalto" e, mesmo, ousemos, o carácter de revelação. Nessa extraordinária passagem, Kafka afirma: "Toda esta literatura é assalto contra as fronteiras e, se o sionismo não tivesse intervindo, ela teria podido chegar facilmente a uma nova doutrina secreta, a uma cabala. (...) É verdade que uma tal tarefa exige gênio, um gênio tão incompreensível que se enraíza novamente nos antigos séculos ou recria os antigos séculos e não dispensa todas as suas forças neste trabalho, mas começa apenas a usá-las.”

É sempre um risco a análise desta passagem, pois jamais saberemos exactamente o que Kafka queria dizer, mas a presença poderosa de uma atmosfera de religiosidade e de magia da linguagem pode ser deduzida da sua afirmação. Podemos concluir, assim, que existe indubitavelmente uma espécie de atmosfera de religiosidade que se esconde nos seus

\footnotetext{
${ }^{13}$ Em A Metamorfose, Kafka retoma esse embaraço, ao contar a história de Gregor Samsa que se transforma subitamente em insecto e se vê rejeitado pela família e pela sociedade. Metáfora de um mal-estar atávico, a Metamorfose hiperboliza bem essa incapacidade de integração da sociedade e da família.

${ }^{14}$ MOSĖS, Op. cit., p. 213.

${ }^{15}$ Tal é a opinião de Benjamin, Scholem, Löwy e muitos outros autores. No entanto, gostaria de referir uma passagem de Robert Alter, que diz exactamente (e de forma muito clara) justamente o inverso. Cf. ROBERT ALTER, Les Anges Nécéssaires, p. 87: "Apesar do seu interesse pelas questões relativas ao judaísmo e pela cultura judaica a partir de 1911 e, apesar dos seus esforços para estudar hebreu durante os últimos seis anos da sua vida, Kafka exclui rigorosamente da sua ficção toda e qualquer referência ao que quer que seja judaico, à excepção de um único conto, "O Animal na sinagoga» (...) Nada à superfície dos romances e dos contos trai o facto de o autor ser judeu." Mas, para Kafka, de acordo com Alter, a questão não era a de ocultar a sua condição judaica, mas justamente a de "converter os tormentos de uma existência judaica em imagens que traduzissem os dilemas essenciais da humanidade" (p. 88).

${ }^{16}$ KAFKA, Journal, Grasset, Livre de Poche, Paris, 1954, p. 530.
} 
romances e nos seus contos, sob a forma da parábola, inquietante e enigmática e que foi muito bem compreendida por Walter Benjamin.

Se Max Brod reconhecia na obra kafkiana um messianismo positivo e cheio de esperança $^{17}$, Benjamin não concordava ${ }^{18}$ em absoluto, e a obra kafkiana é, ela própria, uma prova do pessimismo e da negatividade. Ainda que Benjamin e Scholem reconheçam na obra de Kafka a presença do messianismo (e Scholem a presença da revelação ${ }^{19}$ ), há uma estranha conversão desse conceito que leva Benjamin a responder a Scholem, negando a sua interpretação teológica ${ }^{20}$. É preciso compreender o que Scholem pretende dizer com esta enigmática observação sobre Kafka. Em Scholem, o termo de Revelação "traduz a noção hebraica de «Tora»e, conforme a polissemia deste vocábulo, este implica igualmente as noções de Lei e de Doutrina. O «nada da Revelação» [Nichts der Offenbarung] designa, então, um momento paradoxal na história da tradição, o de uma ruptura decisiva (mas não

\footnotetext{
${ }^{17}$ Talvez a única obra onde possa reconhecer-se essa esperança seja na obra América, sobretudo no capítulo "Teatro Natural de Oklahoma". Uma conversa mantida por Kafka e Brod parece ter sugerido a este último o lado paradisíaco e a felicidade reencontrada de Karl Rossmann. Porém, no Diário de Kafka uma anotação deste pareceia prever um final punitivo, completamente ao invés. Profundamente alegórica, essa passagem do seu diário, desmente inteiramente o optimismo de Kafka.

${ }^{18} \mathrm{Na}$ extraordinária carta-ensaio de Junho de 1938, que Benjamin escreve a Scholem, em Briefe, II, pp. 763, 764, Benjamin afirma de forma inequívoca: "Assim, como o afirma Kafka, existe uma esperança infinita, simplesmente ela não é para nós. Esta frase contém realmente a esperança de Kafka. É a fonte da sua irradiante serenidade." Nessa mesma carta, Benjamin explica detalhadamente todas as razões do seu desacordo relativamente a Max Brod, atribuindo todos os defeitos da sua interpretação a uma falta de distância e a uma bonomia desleixada, relativamente a Kafka. Benjamin esperava que, com esta carta, Scholem pudesse conseguir um contrato para um livro.

${ }^{19}$ De acordo com a correspondência trocada entre Scholem e Benjamin - sobretudo nas cartas trocadas no Verão de 1934 - o cerne da interpretação de Scholem consistia no "nada da Revelação" [Nichts der Offenbarung], expressão que Benjamin deseja ver esclarecida. Cf. WALTER BENJAMIN/GERSHOM SCHOLEM, Briefwechsel 1933-1940, Hrsg. Von Gershom Scholem, Francfort-sur-leMain, Suhrkamp, 1980, p. 157: "O mundo de Kafka é o mundo da Revelação, mas na perspectiva em que ela se encontra reconduzida ao seu próprio nada". Na p. 175, responde a Benjamin: "Tu perguntas-me o que é que eu entendo pelo «nada da Revelação». Por isso eu entendo um estado no qual esta se manifesta como vazia de toda a significação, ou seja, em que ela continua a afirmar-se, onde conserva a sua validade, mas onde ela já não significa. Aí, onde a riqueza das significações se dissipa, sem que desapareça por isso a manifestação, mesmo que o seu conteúdo se encontre reduzido, por assim dizer, ao grau zero (e a Revelação é bem qualquer coisa que se manifesta), é aí que aparece o nada dessa manifestação. É claro que, do ponto de vista da religião, trata-se de um caso limite e ele é mais que duvidoso que um tal caso se possa efectivamente realizar."

${ }^{20}$ A 20 de Julho de 1934, quando se encontrava já na Dinamarca e em pleno auge das suas discussões com Brecht sobre Kafka, Benjamin afirmava a Scholem: "Kafka tentou roçar o dedo na redenção", mostrando a preocupação kafkiana relativamente ao messianismo. (Briefe, II, p. 614). Cf. também a carta de Benjamin a Scholem, de 11 de Agosto de 1934, onde Benjamin esclarece esquematicamente as suas posições sobre Kafka: «eu não nego o aspecto da revelação na obra de Kafka (...) reconheço no seu lugar o aspecto messiânico. A categoria messiânica em Kafka é a "conversão" ou o "estudo"».
} 
definitiva), em que a Lei já perdeu o princípio da sua autoridade, mas onde a sua sombra continua ainda a perfilar-se no horizonte da nossa cultura ${ }^{21}$.

Trata-se, assim, de um «caso limite da religião», sempre ameaçado pelo ateísmo, nas suas diversas formas, seja ele simples e puro, seja nas suas formas mais radicais e de angústia profunda. Mas, como o reconhece Mosès, “é precisamente esta instabilidade, esta errância de uma parte e de outra de uma fronteira, ela própria versátil, que impede de compreender o «nada da Revelação» em termos da lógica dos contrários e que nos permite entrever o sentido que atravessa os meandros da ficção" 22 .

Esta tese de que a Revelação conserva ainda a sua validade, mesmo que "esvaziada de todo o seu significado" - podendo, ainda, erigir-se como uma categoria interpretativa distingue a posição benjaminiana da de Scholem. Enquanto que, para Benjamin ${ }^{23}$, na figura paradigmática do estudante como emblema dessa ambivalência face à Revelação, o autor fala do estudante como aquele que, simbolicamente, "perdeu a Escritura"; para Scholem, essa figura reenvia para uma outra interpretação, oposta. Este compreende o estudante como o "representante simbólico de uma época que já não sabe decifrar a Escritura"24. O que Scholem pretende é dizer que, mesmo que a Revelação - os textos da tradição judaica - nos pareçam incompreensíveis, a tradição não desapareceu de vez e que certamente haverá uma época em que ela seja, de novo, acessível aos homens. A questão essencial (e que ganha relevo particular no nosso caso) é a de saber se a tradição é capaz de se renovar radicalmente, de tal modo que lhe seria devolvido uma pertinência que ela havia perdido. É bem esta a preocupação central dos nossos autores e o objecto crucial do seu pensamento. Mesmo que a questão não seja explicitamente formulada, a problemática permanece latente no pensamento, quer de Scholem e de Benjamin, como de Rosenzweig, de Bloch ou de Kafka.

Reencontrar, como o afirma com frequência Hannah Arendt, no seu belo ensaio Homens em Tempo de Sombra, a "pérola" ou o tesouro que se esconde no fim do mar é claramente o objectivo de Benjamin, mas não o é menos dos outros autores. Cada um, à sua maneira, procurou reavivar o que parecia ser uma "tradição moribunda" para reencontrar o verdadeiro sopro, a respiração autêntica de algo que ainda vivia na memória. Por isso se explica a revolta e a angústia (e também a culpabilidade) de Kafka, a de nunca ter conhecido

\footnotetext{
${ }^{21}$ STEPHANE MOSES, Op. cit., p. 223.

22 Ibidem, p. 224.

23 Refiro-me à carta de Benjamin a Scholem, em Briefe, II, p. 437.

${ }^{24}$ Benjamin/Scholem, Briefwechsel, p.158.
} 
essa tradição, senão numa forma arruinada e adulterada. Ou, dizendo de outro modo, como se ela tivesse submergido nas águas do esquecimento.

Como o afirma de uma forma precisa Robert Alter, referindo a tríade Scholem/Benjamin/Kafka, "eles são os três modernistas com os rostos voltados para o horizonte da tradição." 25 Esse é o significado do "anjo" que aparece na obra de cada um dos autores, sem dúvida. Enquanto que o anjo kafkiano evoca a tradição, mas revela, ao mesmo tempo, a incapacidade de olhar para trás, o anjo de Benjamin, bem como o de Scholem configuram-se em toda a sua forma paradoxal, "encravados" entre a tradição e a modernidade emergente, na incapacidade de conciliar tradição e modernidade, cada um à sua maneira: Scholem na teologia e na teoria linguística da cabala e da mística, Benjamin na prosa filosófica e na apresentação da sua teoria da tradução e da linguagem, enquanto expressão máxima dessa presença do judaísmo, Kafka na sua ficção, inscrevendo-lhe uma visão profundamente alegórica e enigmática, única no seu tempo, que criou um género e lhe deu morte.

\section{É possível falar do messianismo em Kafka?}

Para Kafka, e se nos é permitido assim falar, a vinda do Messias parece estar estreitamente ligada a uma concepção individualista da fé, totalmente alheia à ideia da comunidade $^{26}$. Num aforismo que o autor escreveu em Novembro de 1917, afirma: "O Messias virá a partir do instante em que o individualismo mais desregrado for possível na fé quando já não houver ninguém para destruir essa possibilidade e ninguém para tolerar essa destruição, ou seja, quando os túmulos se abrirem"27 e a 4 de Dezembro complementa a sua afirmação com uma outra: “O Messias só virá quando não for mais necessário, só virá um dia após a sua chegada, não virá no último, mas depois do último dia”.

Que quer, de facto, dizer Kafka? Que acreditaria, à maneira de Buber, de Rosenzweig ou de Benjamin, que a redenção messiânica é obra do homem, ao fazer desabar os constrangimentos exteriores? Desta forma, a redenção messiânica prefigura a "era da liberdade humana" e não o advento de algo que irrompe alheio à vontade humana. A confirmar essa ideia parece estar a sua parábola "Chacais e árabes" (de 1917), onde critica

\footnotetext{
${ }^{25}$ Les Anges Nécéssaires, p. 109. Esta imagem evoca o "anjo da história", nos casos de Benjamin e Scholem, explicitamente. Mas, no último capítulo do seu livro, Alter refere a presença do "anjo de Kafka", também, que não consideramos oportuno desenvolver aqui. Esse anjo seria, à maneira kafkiana, uma correspondência com o Angelus Novus, de Benjamin e de Scholem.

${ }^{26}$ Nesse sentido, Kafka está muito mais próximo do hassidismo de Buber.

${ }^{27}$ Citação de Michael Löwy, em Redenção e Utopia, p. 72.
} 
impiedosamente aspectos da tradição religiosa judaica como a espera passiva de um Deus salvador e o desejo de vingança sobre as outras nações.

Na obra de Kafka - contrariamente ao optimismo de Max Brod - não existia nada de doutrina positiva, dessa promessa utópica vaga e difícil de formular, mas ante e ao invés a “Theologia negativa de um judaísmo que perdeu o sentido positivo da Revelação". Assim, não apenas Scholem e Benjamin, como igualmente Adorno ${ }^{28}$ compreendem na redenção messiânica, sob a sua forma negativa, uma dimensão fundamental e geradora dos escritos kafkianos. A concepção de teologia negativa parece ser aquela que melhor explica, com maior profundidade, os aspectos religiosos da obra kafkiana. Neste sentido, a interpretação destes autores coloca-se nos antípodas da interpretação de Max Brod, que, ao procurar reabilitar a obra de Kafka, falsificou determinados aspectos, escamoteando-os. O exemplo mais flagrante dessa interpretação de Brod encontra-se no prefácio à primeira edição de $O$ Castelo, onde não hesita em dizer que "esse 'Castelo', onde Kafka não obtém o direito de entrar, e do qual não pode mesmo aproximar-se, é exactamente a 'Graça' no sentido dos teólogos, o governo de Deus que dirige os destinos humanos" ${ }^{29}$. Mesmo os aspectos mais tenebrosos da obra são por ele interpretados como demonstração de que as categorias da moral e da religião não coincidiriam, insistindo numa leitura "positiva".

Para Benjamin, tal interpretação era, no mínimo, grosseira e, longe de ser o símbolo da Graça, o Castelo parece enquadrar-se numa lógica alegórica e infernal, de um mundo onde a Graça se fez ausente ${ }^{30}$. Mais próximo de Strindberg e de Benjamin, que consideravam que "O inferno é esta vida aqui”, ninguém compreendeu melhor que Adorno que em $O$ Castelo, a nossa existência é, antes, perspectivada como o "Inferno visto do ponto de vista da redenção". No romance, 'o Castelo' encarna o Poder, a Autoridade, o Estado, em face do povo, que é representado pela 'Aldeia'. Expressão do poder alienado e arrogante, inacessível, é ele que governa a 'Aldeia', através do seu labirinto burocrático e absurdo. Kafka apresenta assim um mundo reificado, onde a importância singular do homem se dissipa, face a uma engrenagem monstruosa e cega. O homem é impotente perante esse aparelho indecifrável (estrutura que se repete em $O$ Processo). O rosto sem reconhecimento ou o mundo decaído são bem a expressão desse Inferno em vida e toda a tentativa humana está, desde o seu início, condenada

\footnotetext{
${ }^{28}$ Numa carta redigida a Walter Benjamin de Adorno, in HENRI LONITZ, ed., Correspondance AdornoBenjamin, traduction de l'allemand par Philippe Ivernel, La Fabrique éditions, Paris, 2002, pp. 76-83.

${ }_{29}^{20}$ LöWY, Redenção e Utopia, p. 73.

${ }^{30}$ Já no seu texto sobre Kafka, lido por Benjamin na rádio de Frankfurt, em 3 de Janeiro de 1931 e que será posteriormente retomado no grande ensaio sobre Kafka de 1934, Benjamin refuta vigorosamente as teses de Max Brod.
} 
ao seu fracasso. Ao mesmo tempo, o carácter alegórico e desencantado do olhar kafkiano jamais sucumbe ao patético, mas conserva a mais absoluta sobriedade e a ironia cáustica, a expressão mais acabada do niilismo. Poderíamos, assim, reconhecer na obra kafkiana, do ponto de vista benjaminiano, a expressão de um mundo desencantado, "onde a redenção messiânica só se manifesta negativamente, pela sua ausência radical”. Essa ausência manifesta-se duplamente, ao mesmo tempo, pela não-presença de Deus no mundo e pela nãoredenção dos homens. Podemos, ainda, reconhecer na segunda a consequência directa da primeira.

Na esteira de Scholem e da sua teoria, Löwy reconhece no messianismo negativo de Kafka, não apenas a teologia negativa, como também uma utopia negativa, na verdade, um anarquismo negativo ${ }^{31}$. Essa dimensão vai acrescentar-se às outras, conferindo à sua obra um aspecto peculiar, uma presença de uma crítica constante à autoridade burocrática e essa violência crítica atravessa toda a sua produção. É, com efeito, em A Colónia Penal que o antiautoritarismo alcança o seu clímax, onde o condenado à morte escreve (e inscreve) no seu corpo a violência da Lei. Scholem compreendeu admiravelmente que todas as personagens de Kafka apenas se definem pela sua relação de proximidade ou de afastamento à Lei, convertendo-se esta no pano de fundo no qual se movem todas as figuras kafkianas, na mais acabada e expressiva das formas alegóricas, isto é, evidenciando o carácter absurdo da Lei. Porém, curiosamente, nessa terrível parábola que é A Colónia Penal, já não é são o explorador, nem tão pouco o oficial ou o prisioneiro - as personagens centrais da parábola kafkiana, mas a Máquina (também ela configura-se como a expressão terrível da instrumentalização e da ausência da organicidade e da própria vida, onde o humano perde completamente a sua expressão), na mais atroz descrição do seu funcionamento.

Nessa inquietante parábola, a máquina não existe para executar o homem, como um mero instrumento da Lei, mas ela é um fim em si e o homem é dela o seu instrumento, desenhando o mais terrível exemplo de uma estética vazia do mal ${ }^{32}$. Löwy, na sua admirável interpretação, afirma: “A autoridade aparece aqui em sua figura mais alienada, mais reificada, enquanto mecânica "objectiva": fetiche produzido pelos homens, ela os subjuga, os domina, os destrói” ${ }^{33}$. Reificação da autoridade, que reduz o homem à sua condição de pura alienação,

\footnotetext{
${ }^{31}$ LöwY, Op. cit., p. 75.

32 Não posso deixar de evocar aqui os admiráveis textos de Hermann Broch que tratam exactamente dessa estética vazia do mal. Permitam-me remeter o leitor para um texto que publiquei em http://www.ucm.es/info/especulo/numero27/h broch.html, onde abordo precisamente 0 tema em questão.

33 Ibidem, p. 180.
} 
a Máquina converte-se também na reificação do mal, simbolizando a eclosão da Primeira Guerra Mundial.

Benjamin compreendeu profundamente a dimensão crítica da obra de Kafka sob o ponto de vista do homem moderno. Na carta que dirige a Scholem, a 12 de Junho de $1938^{34}$, ele esclarece demoradamente os aspectos centrais da obra de Kafka. Nessa mesma carta, Benjamin situa o universo da obra kafkiana entre a experiência mística - mesmo que ela não seja a da tradição habitual - e a experiência do homem da grande cidade moderna, com todas as consequências devastadoras na experiência tomada no seu sentido tradicional. De uma forma visionária, Kafka põe a nu as fissuras da "bela arquitectura" da tradição judaica, no sentido em que a sua obra apresenta uma tradição decadente e doente, enferma do fetiche, da alienação, anunciando profeticamente um mundo arruinado. É por essa razão, explica-nos Benjamin, que, na sua obra, só "se mantêm os elementos desintegrados" 35 e "a loucura é a essência das personagens preferidas de Kafka" ${ }^{\text {"36 }}$. O homem encontra-se, do seu ponto de vista, reduzido à sua condição de criatura, de animalidade, como o atesta Gregor Samsa ${ }^{37}$, no seu desespero, renunciando em absoluto à sabedoria humana.

Num ensaio que Benjamin consagrou, em 1936, a Leskov, ele definira a narração como a transmissão de uma sabedoria e essa mesma sabedoria representava, para si, "a face épica da verdade" ${ }^{38}$, exprimindo assim uma coerência interna na visão do mundo, uma totalidade e uma "bela harmonia" que se dissipou na modernidade. Ora, é precisamente esta coerência que já não existe na obra de Kafka e a expressão desse desaparecimento é precisamente o Castelo, que põe em cena, através do seu aspecto labiríntico e pela fragmentação do discurso narrativo, a própria dissolução da ideia de verdade. Em Kafka, como muito bem escreve Benjamin, é a consistência "haggádica" da verdade que desapareceu $^{39}$. Um mundo marcado, como já referimos anteriormente, pela tradição doente e moribunda, mas onde a genialidade de Kafka está, a atentar nas palavras de Benjamin, "no facto de ter experimentado qualquer coisa totalmente diferente; ele renuncia à verdade para

\footnotetext{
${ }^{34}$ Briefe, II, pp. 756-764.

${ }^{35}$ Briefe, II, pp. 763, 764.

${ }^{36}$ Ibidem.

37 Ibidem: "Ser animal, para ele, significa, sem dúvida, ter renunciado, por uma espécie de pudor, à figura e à sabedoria humanas". Cito ainda, a este propósito, o estudo notável de STÉPHANE MOSĖS, Exegese d'une legende, éditions de l'éclat, Paris, 2006, no capítulo "La Polysémie dans la Métamorphose", pp. 47-70.

38 WALTER BENJAMIN, Écrits Français, présentés par J.M. Monnoyer, Paris, 1991, p. 209: "A arte de narrar está em declínio porque o aspecto épico da verdade, a sabedoria, tende a desaparecer.

${ }^{39}$ Brieffe, II, p. 763: "Diese Konsistenz der Wahreit ist es, die verloren gegangen ist".
} 
não abandonar a transmissibilidade, o seu elemento haggádico" ${ }^{40}$. Mais do que parábolas, "elas não se deitam pacificamente aos pés da halacha (...) elas elevam contra ela uma enorme garra"41.

Dir-se-ia que a genial e incontornável obra de Kafka repete as figuras alegóricas de Benjamin, devoradas pela loucura ${ }^{42}$ e pela melancolia barroca. A figura de Joseph K., no final de O Processo, que "morre como um cão", dá-nos também a ver essa redução à mais baixa condição humana (que também é a condição dos que sucumbem à acedia, no Trauerspiel), a da submissão cega à autoridade, retirando, assim, a possibilidade da liberdade e da esperança ao homem; retirando-lhe igualmente qualquer possibilidade de redenção da experiência humana. É por essa razão que a obra de Kafka aparece a Scholem como a mais desesperada representação metafórica do nosso mundo moderno "de onde Deus se retirou"43.

Para Scholem, todavia, o mal-estar kafkiano é um sintoma de que padece a tradição mística judaica (Kafka serviu-lhe bem de ponto de partida na análise da tradição mística). Como ele o afirma, essa dicotomia que Benjamin compreendeu tão lucidamente em Kafka, não é especificamente própria da Haggadah kafkiana, isto é, "a antinomia do elemento haggádico (...) ela está implicada na própria natureza da Haggadah (...) Esta 'doença' faz parte da própria essência da tradição mística"44. Contrariamente a Benjamin, que vê na fragmentação da narração Kafkiana a impossibilidade da mesma, Scholem pensa que a crise da tradição, isto é, da narração, que a obra de Kafka reflecte, é um testemunho da tênue possibilidade de contar a história. A acordar com Scholem, na medida em que Kafka narra (e se dá conta do desaparecimento da tradição), então é ainda possível falar de «narração» ${ }^{45}$.

Para Benjamin (como de resto para a maioria dos autores que interpretaram a sua obra), a escrita de Kafka tem uma estrutura de parábola, isto é, de histórias codificadas que remetem para uma enigmática significação que se oculta e que impele o seu leitor a perseguir obstinadamente esses traços ocultos em busca de um sentido. Porém, em vez das parábolas habituais - as que encontramos na literatura religiosa - encontramos uma forma alegórica de

\footnotetext{
${ }^{40}$ Ibidem.

${ }^{41}$ Ibidem.

42 Evoco o texto A Origem do Drama Barroco Alemão (Ursprung des deutschen Trauerspiels), onde Benjamin desenvolve a sua teoria da alegoria. Relembro a figura do príncipe, corroído pela tristeza melancólica, a redução à mais pura bestialidade, que é o apanágio da accedia. Também Stéphane Mosès, na sua obra L'Ange de l'Histoire, p. 229, chama a atenção para essa relação íntima: "Essa decadência sem recurso que Scholem descobre e que relembra a descrição do mundo barroco em Walter Benjamin, é a de um universo irremediavelmente corrompido e que não pode ser salvo".

${ }^{43}$ BENJAMIN/SCHOLEM, Briefwechsel, p. 158.

44 BENJAMIN/SCHOLEM, Briefwechsel, p. 272.

${ }^{45}$ Ibidem, pp. 272-273.
} 
narrar, enganadora e vertiginosa. Tal como ele nos referia, ao referir-se à estrutura vertiginosa do Drama Barroco Alemão; que lançava o alegorista nos "abismos da significação", perdendo-se de símile em símile, na promessa da lúmen naturale do saber ${ }^{46}$; também a forma alegórica de Kafka contém essa remissão enganadora para as portas que se abrem para quartos vazios e onde nada existe, fazendo da ilusão repetida e mecânica o seu truque. Como nos diz Benjamin no seu admirável ensaio redigido em 1934, o mundo de Kafka é o mundo da letargia, de personagens senis e sonâmbulos mergulhados nos seus quartos obscuros e em galerias intermináveis, repetindo uma estrutura espacial que já encontrávamos também no texto A Origem do Drama Barroco Alemão (Ursprung des deutschen Trauerspiels). Tal como neste texto sobre a compreensão do homem barroco sobre a vida, também o mundo de Kafka é um grande teatro e a expressão mais acabada dessa visão é, com efeito o grande teatro de Oklahoma. A vida tomada como uma ilusão, em que cada sujeito não desempenha senão um papel, num jogo permanente de ilusões e de significações que se escondem umas atrás das outras, como um espelho que repete vertiginosamente os seus simulacros.

O paralelo que Benjamin estabelece entre os personagens de Kafka, devorados pelo seu carácter ilusório e vazio, e os seis personagens de Pirandelo que "andam em busca de um autor" é bem o exemplo de um universo em que nada vale por si e a singularidade do indivíduo não possui qualquer valor, mas apenas a sua natureza espectral e ilusória. É também o mundo do exílio desamparado e triste, onde o indivíduo vive na carne a condição do estrangeiro, hostilizado por todos. Na nossa opinião, a compreensão benjaminiana da estrutura alegórica da narração kafkiana deve imensamente ao texto A Origem do Drama Barroco Alemão, nas suas secretas e múltiplas repercussões. Desta trama alegórica, poderosamente destrutiva e aniquiladora resulta a visão benjaminiana do mundo arruinado de Kafka, pois a alegoria crava nele uma desintegração irreversível.

Curiosamente, segundo a pertinente interpretação de Marthe Robert, que reserva para si uma dose de esperança - e neste sentido se destaca das interpretações de Scholem e Benjamin na interpretação da obra de Kafka, ainda há uma possibilidade de salvação. E o autor reconhece-a em O Castelo, considerando que o Agrimensor K. representa uma etapa nova no desenvolvimento do homem (relativamente a Joseph K.) na "lenta marcha do herói, rumo à conquista do seu Eu sobre a tirania do 'administrativo': ele morre esgotado, mas ao menos “desmontou peça por peça, símbolo após símbolo, signo após signo, a construção toda poderosa que só se mantém de pé graças ao arbítrio dos seus senhores, devidamente

${ }^{46}$ WALter BenJamin, G.S., I, 1, Suhrkamp Verlag, Frankfurt am Main, 1974, p. 407. 
secundados pela pobreza de espírito e credulidade dos indivíduos cegos". ${ }^{47}$ O espanto só é possível àquele que é estrangeiro (remissão à condição do judeu) à Lei, numa situação de exterioridade face à relação de dominação entre o Castelo e a Aldeia. Pela dignidade que lhe é ínsita, ele não pede nenhum favor, mas exige o seu direito, algo que é impossível de cumprirse neste universo.

A nossa intenção, ainda que a obra de Kafka exerça um enorme fascínio sobre o leitor e as interpretações sobre o autor sejam inesgotáveis, não é a de levar a cabo uma exegese demorada e detalhada, mas antes procurar os elos que o ligam à constelação de autores aqui analisada (Scholem, Bloch, Buber, Rosenzweig, Benjamin), definindo os elementos que constituem o mais importante na ligação entre Kafka e Benjamin, do ponto de vista do messianismo, da compreensão da modernidade alienada e do fracasso como condição inalienável do homem moderno. Compreendemos bem a importância de um autor como Kafka, ao lado de Baudelaire e de Proust, para compreender a paixão benjaminiana pelo seu estudo. Tanto Kafka, como Baudelaire ou Proust, de formas diferentes e ambas inesgotáveis, na sua análise, serviram a Benjamin para levar a cabo o diagnóstico do mal-estar moderno e permitiram-lhe encontrar uma matriz riquíssima, para fundar, a partir desses autores, a sua interpretação da alegoria, numa espécie de fio condutor que tem o seu ponto de partida no texto A Origem do Drama Barroco Alemão.

Se é que podemos afirmar duas linhas fortes de pesquisa, neste trabalho, elas são claramente a configuração do traço messiânico na obra de Benjamin, por um lado, e, por outro, a sua relação intrínseca com a teoria benjaminiana da alegoria, relação por certo densa e obscura, mas incontornável. A morte da tradição mística e judaica, o seu rosto moribundo, à luz de uma modernidade desencantada e secularizada, aflora constantemente na obra de Benjamin sob a forma da alegoria, como a melhor expressão de "dar a ver a facies hippocratica da história que se oferece ao espectador como uma paisagem primitiva petrificada", como o afirmou Walter Benjamin em Origem do Drama Barroco Alemão ${ }^{48}$. A profundidade da teoria benjaminiana da alegoria comporta inúmeras ramificações para a análise da ruína e do fragmento, a fractura da linguagem, o despedaçamento do corpo e da organicidade, de modo que a análise da obra de Kafka será, num período de maturidade literária - onde Benjamin já desenvolveu todo o seu trabalho sobre a alegoria e se prepara

\footnotetext{
${ }^{47}$ MARTHE ROBERT, Seul, comme Franz Kafka, pp. 230, 231.

${ }^{48}$ Origem, G.S., I, 1, p. 343: "Während im Symbol mit der Verklärung des Unterganges das Transfigurierte Antlitz der Natur im Lichte der Erlösung flüchtig sich offenbart, liegt in der Allegorie die facies hippocratica der Geschichte als erstarrte Urlandschaft dem Betrachter vor Augen".
} 
para a análise de Baudelaire e da modernidade, para a redacção dessa obra colossal que é $A s$ Passagens -, um lugar privilegiado de reflexão onde desaguam as suas preocupações fundamentais. 
"A próxima cidade" ou a história de um desencontro entre Benjamin e Brecht.

O meu avô tinha o hábito de dizer «A vida é espantosamente breve. Agora, na minha lembrança, ela fecha-se de tal maneira sobre ela mesma que eu compreendo apenas, por exemplo, que um homem jovem possa decidir-se partir a cavalo para a mais próxima aldeia sem temer que - com todas as ideias de um infeliz incidente afastadas - a duração de uma vida ordinária, desenrolando-se feliz, não seja suficiente, nem de longe, para uma tal cavalgada.» *

KAFKA, Un Médecin de campagne.

No final de Junho de 1934, cerca de um ano após ter saído da Alemanha, numa época em que se tornara impossível a sobrevivência dos judeus, Benjamin encontrava-se na Dinamarca, a convite de Brecht, onde permaneceu quase um ano. Consigo, Benjamin trazia o manuscrito de um artigo sobre Kafka, que lhe havia sido encomendado pelo semanário Die Jüdische Rundschau (o órgão informativo do movimento sionista alemão), por intermédio do seu amigo Scholem. Já havia enviado esse artigo a Scholem, redigido em seis semanas atribuladas, antes da sua partida para a Dinamarca, e aguardava com impaciência a sua reacção. Hesitou algumas semanas antes de o dar a ler a Brecht. Conhecia a opinião deste relativamente a Kafka e à sua obra ("um grande escritor, como Kleist, mas que definitivamente havia falhado, Grabbe ou Büchner"49), pelo que temia o seu juízo sobre o ensaio.

O acto de Benjamin, ao dar-lhe a ler o seu ensaio sobre a obra de Kafka, dá origem a um debate violento ${ }^{50}$ entre os dois homens. A Brecht, o ensaio de Benjamin sobre Kafka irrita-o, pelo facto de ser tratado fora do seu contexto biográfico e social. "Em lugar de estudar a situação concreta na qual Kafka viveu (...) Benjamin retorna sempre à questão da essência (da obra de Kafka)" ". Brecht contesta a "profundidade" da análise de Benjamin, dizendo-lhe que não deveria ocupar-se com tais ninharias. Não se trata, como se pode ser levado a pensar, de um olhar cínico o que aqui se esconde, mas precisamente a marca de um

\footnotetext{
*Tradução minha a partir do texto francês.

${ }^{49}$ Cf. WALTER BENJAMIN, G.S., VI, "Fragmente Autobiographische Schriften", p. 525. Considero este breve texto precioso, para dar conta de todos os passos dessa discussão marcante, entre Brecht e Benjamin. Ver também a obra de StÉPHANE MOSĖS, Exegese d'une legende, éditions de l'éclat, Paris, 2006, p. 72.

${ }^{50}$ BENJAMIN, G.S., VI, p. 528. Numa das acusações mais insultuosas de Brecht a Benjamin, aquele dizia que o seu ensaio sobre Kafka "favorecia o fascismo judeu. Ela aumentaria e espalharia a obscuridade em torno da personagem, em lugar de a dissipar."

${ }^{51}$ WALTER BeNJAMIN, Op. cit.,p.527.
} 
compromisso profundo com o factor social, que caracterizou a sua obra e o seu programa estético. Em resposta a Brecht, Benjamin sugere-lhe a leitura do pequeno excerto "A Próxima Cidade". Ilustrando a brevidade da vida e a experiência vivida e subjectiva do avô, esta parábola tem imensas repercussões no pensamento de Benjamin que se prendem com a sua própria noção de experiência [Erfahrung], de tempo vivido, de rememoração [Eingedenken] também, que, desde sempre, ocuparam a sua reflexão.

Mosès compreende com grande clareza a questão "do paradoxo de um tempo, simultaneamente muito longo e ridiculamente curto" que "perde o seu carácter de aporia para aparecer (...) como o efeito de uma desformalização do sentido da duração" ${ }^{52}$. Essa é, a meu ver, a questão fundamental - e a que Brecht não foi capaz (ou não quis) de aceder. Isto é, Brecht compreendeu imediatamente o carácter aporético do texto ${ }^{53}$, mas não enveredou pelo ponto de vista benjaminiano, que descortinou o que se ocultava para lá do seu carácter aporético: a questão da rememoração ${ }^{54}$, por um lado, e a da desformalização do tempo, por outro. A contra-interpretação da parábola, por Benjamin, liga-se, assim, a uma das questões que lhe são caras e que é a questão da rememoração - que aqui nos limitamos a aflorar. Esta converteu-se, como se sabe e veremos posteriormente, num dos traços essenciais do pensamento benjaminiano, relativamente à sua concepção da alegoria, e que Benjamin aplicou igualmente à interpretação da obra de Proust e de Baudelaire, como um dos aspectos nucleares da sua obra e que conhecerá o seu esplendor derradeiro no Livro das Passagens.

"A cidade mais próxima" deixa-nos a ideia de que, quanto mais envelhecemos, mais manifesta se torna a função e a importância da memória. Como ele o diz na sua passagem enigmática, o impulso para que tende a rememoração é a "descoberta de si próprio", fugindo ao presente. Descoberta, como podemos ousar a compreensão, da história e da tradição, tanto mais que esta passagem surge associada à ideia da escrita. Poderíamos, ainda, ousar aproximações ao prefácio da obra A Origem do Drama Barroco Alemão ${ }^{55}$, onde Benjamin

${ }^{52}$ STEPHANE MOSES, Op. cit., p. 78.

${ }^{53}$ G.S., VI, p. 529. Alter, na sua obra Les Anges Nécéssaires, pp. 161, refere a leitura de Brecht e Benjamin, dizendo que, ao reduzir o enigma de Kafka a um esquema lógico, escamoteando o seu elemento de obscuridade, ainda que seja uma interpretação inegavelmente inteligente, tal opera uma redução que se coloca ao serviço da concepção estética de Brecht, afirmação com a qual concordamos inteiramente.

54 WALTER BENJAMIN, Op. cit.,p. 529: "Pela minha parte, faço o seguinte comentário: a verdadeira medida da vida é a rememoração [Erinnerung]. Ela percorre a vida, retrospectivamente, num clarão." E continua, de forma enigmática: "Aqueles para quem a vida se transformou em escrita, como os Antigos, não podem ler esta escrita senão recuando. É somente assim que eles se reencontram a si próprios, e que eles a podem compreender - fugindo ao presente."

${ }^{55}$ Limito-me a formular essa aproximação a um tema que, aqui, se revela inoportuno desenvolver. Não queria, no entanto, deixar de alertar o leitor para esta íntima relação que aqui se esboça e é 
estabelece uma profunda articulação entre a prosa filosófica, rememoração [Eingedenken] e apresentação [Darstellung]. Robert Alter vê neste recurso ao passado a própria "estrutura imanente da tradição judaica. Tudo tinha a sua fonte na incandescência da revelação, transmitida através dos tempos pela miríade de espelhos e refracções da exegese"56 Porém, esta orientação, segundo o autor, e que aparece nas figuras judaicas modernas, nada tem que ver com o mito grego da Idade do ouro, de um retorno ao Éden.

Para Brecht, contrariamente, a "ideia central do texto de Kafka é a de uma deficiência fundamental do tempo: para Kafka, qualquer que seja o tempo de que o homem dispõe, ele não será jamais suficiente para lhe permitir realizar a sua tarefa" ${ }^{\natural 7}$. O fundo geral que se apresenta aos olhos de Brecht é sempre o tempo histórico e as histórias de Kafka padecem de um pessimismo inultrapassável, que Brecht recusa em definitivo. Walter Benjamin, todavia, apresenta uma interpretação muito diferente (e que o remete, de forma sibilina, para a componente messiânica da escrita kafkiana). Neste sentido, a sua interpretação da obra de Kafka, ainda que na sua singularidade irredutível, aparece claramente articulada com a visão de Scholem, pois ambos se encontram mais próximos dos problemas e das preocupações que animam o coração da sua obra.

Para Benjamin, como compreendemos claramente, não lhe interessa a dimensão social da obra kafkiana, nem tão pouco a compreensão da sua obra à luz de uma configuração específica (social e política), mas a "essência", como Brecht o acusa, maliciosamente. A questão da tradição e da modernidade da obra kafkianas são o grande leitmotiv da sua interpretação, bem como a crítica de Kafka ao mito, continuada em Baudelaire - e que tão importante foi na obra de Benjamin. O enigmático lado visionário e profético é também um dos aspectos essenciais que transparece, sobretudo, na sua correspondência com Scholem, partilhando com ele inúmeros aspectos da sua compreensão, mas discordando de Scholem na questão da Revelação, por exemplo. A leitura atenta desses períodos de correspondência entre os dois permite dar a ver, em filigrana, não apenas a sua compreensão da obra de Kafka, mas algo de muito mais universal e abrangente: o modo como a leitura de Kafka e a sua interpretação permitem convocar questões essenciais da obra de Benjamin (e também de Scholem). Aparece aqui, também, na correspondência e no ensaio sobre Kafka, a importância

lembrada, pois à época em que Benjamin redigiu estes textos e notas sobre Kafka, já se encontrava redigida a obra citada aqui, num intervalo que ronda quase dez anos. Esta objecção dá, também, conta da constância dos grandes temas benjaminianos que nunca são abandonados, mas, pelo contrário, retomados e revistos, actualizados.

${ }_{57}^{50 B E R T}$ ALTER, Op. cit., p. 168.

${ }^{57}$ STÉPHANE MOSĖs, Op. cit., p. 86. 
que Benjamin conferiu à dimensão do gesto, como um dos elementos fundamentais que Benjamin compreende na obra de Kafka. De Kafka - e da dimensão ocupada pelo gesto - dirá Benjamin: "Eu não conheço nada na literatura que indique, ao mesmo nível, o gestus de Kafka" ${ }^{, 5}$. E na versão definitiva do ensaio, o autor afirma: "Para Kafka, havia coisas que não eram compreensíveis senão sob a forma de gestos. E os gestos, que ele não compreendia, formavam as partes nebulosas das suas parábolas. É assim que procede a criação literária em Kafka."59

Estabelecendo na obra de Kafka, o primado da alegoria sobre o simbólico, formulando, a partir da sua obra, as questões que lhe são essenciais, Benjamin faz de Kafka um dos autores do seu panteão, privilegiando-o, ao lado de Baudelaire e de Proust. Mesmo que Benjamin se tenha afastado da sua primeira fase (das preocupações religiosas e do judaísmo em particular), voltando o seu interesse para o materialismo dialéctico, o que aconteceu a partir de 1924, o seu interesse pela obra de Kafka traduz, no entanto, a sua nostalgia pela tradição, tema que jamais será capaz de abdicar no seu pensamento. Seja ele um anjo de olhar e corpo petrificados pela catástrofe (como em Benjamin), dilacerado pela impotência, seja a ilusão transformada num simples artefacto humano (em Kafka), a questão é que aquele que se submete ao seu "olhar" não pode, pura e simplesmente, abandoná-lo, mas age como se fosse possível, ainda, acreditar na ilusão, alumiando a sua escuridão sob a "frágil luz do anjo".

${ }^{58}$ Cito a preciosa carta de Benjamin a Scholem, de 12 de Junho de 1938, in: WALTER BENJAMIN, Briefe, II, p. 761: "Ich kenne in der Literatur Keine Stelle, die im gleichen Grade den Kafkaschen Gestus aufweist." Nesta carta, estão expostas todas as linhas de pensamento de Benjamin, desenvolvidas relativamente a Kafka, nas questões que nos interessam particularmente: 0 messianismo, a tradição.

${ }^{59}$ WALTER BENJAMIN, G.S., II, 2, p. 427. 